\title{
Öğretmenlerin Ölçme-Değerlendirme Uygulamaları ve Yeterlik Düzeyleri: İlk ve Ortaöğretim
}

\begin{abstract}
Mehtap ÇAKAN*
ÖZ: $\mathrm{Bu}$ araştırmanın amacı ilk ve ortaöğretim kademesinde görev yapmakta olan öğretmenlerin sınıf içi ölçme ve değerlendirme uygulamaları bakımından ve kendilerini bu alanda nasıl algıladıkları bakımından aralarında farklar olup olmadığını saptamaktır. Çalışma 2004 yazında ilköğretimde görevli 260 ve ortaöğretimde görevli 244 olmak üzere toplam 504 öğretmenle gerçekleştirilmiştir. Katılımcıların 275 i kadın ve 227 si erkeklerden oluşmaktadır. Araştırmacı tarafından geliştirilen 25 maddelik Likert tipi ölçme aracı veri toplamak için kullanılmıştır. Sonuçlar öğretmenlerin önemli bir kısmının kendilerini bu alanda yetersiz algıladıklarını göstermiştir. İki öğretmen grubu arasında güvenirlik ve geçerliğe dair uygulamalar, soru düzeyleri ve program sürecine dönük alınan tedbirler bakımından anlamlı bir farklılık bulunamamıştır. Fakat ilköğretim kademesindeki öğretmenlerin ortaöğretim kademesindeki öğretmenlere kıyasla kendilerini daha yeterli algıladıkları gözlemlenmiştir. İlköğretim öğretmenleri en sık çoktan seçmeli maddeleri kullanırken ortaöğretim öğretmenleri yazılı yoklamaları tercih etmişlerdir.
\end{abstract}

Anahtar Sözcükler: Öğretmen niteliği, ölçme ve değerlendirme, güvenirlik, geçerlik

\section{Comparison of Elementary And Secondary School Teachers in Terms of Their Assessment Practices And Perceptions Toward Their Qualification Levels}

ABSTRACT: This study aims to compare elementary and secondary school teachers in terms of their in class assessment activities and teacher perceptions toward their qualification levels related to measurement and evaluation knowledge and skills. Twenty-five item

*Yrd.Doç.Dr., Abant İzzet Baysal Üniversitesi, Eğitim Bilimleri Bölümü, cakanmehtap@yahoo.com, cakan_m@ibu.edu.tr 
survey developed by the researcher was administered to 260 elementary and 244 secondary school teachers during summer of 2004. The result indicated that most of the teachers perceived themselves as unqualified in terms of measurement and evaluation applications. On the other hand, compare to secondary school teachers, elementary school teachers perceived themselves more qualified. Although most of elementary school teachers use multiple choice items most frequently, secondary school teachers prefer using essay tests most often than any other item type.

Key Words: Teacher qualification, assessment practices, reliability and validity

\section{GİRIş}

Öğretmen yeterliği eğitim kalitesini doğrudan etkileyen önemli bir faktördür. Öğretmenlik mesleği alan bilgisi, genel kültür ve pedagoji bilgi ve becerisini gerektiren bir meslek dalıdır. Öğretmenlerin sahip olması gerekli olan önemli bir özellikte onların yeterli düzeyde ölçme ve değerlendirme bilgi ve becerileriyle donanık olmasıdır (Daniel ve King, 1998; Gullickson, 1985; Mertler, 1999; Zhang ve Burry-Stock , 2003). Kubiszyn ve Borich (1996) öğretmenlerin bilgi ve beceri sahibi olması gereken ölçme ve değerlendirme konularını şu şekilde sıralamıştır: farklı amaçlarla yapılması planlanan ölçmeler için hangi test türlerinin uygun olduğu, dersin yoklanması gereken hedeflerinin neler olduğunu doğru tespit edebilme, yazılı yoklama türü testlerin nasıl geliştirilmesi gerektiği bilgi ve becerisi, testlerin güvenirlik ve geçerliğinin nasıl sağlanacağ test puanlarının nasıl kullanılması gerektiği ve öğrenci başarılarının yada notlarının etkili bir iletişim tekniği kullanarak ailelere etkili ve yararlı olacak şekilde nasıl iletilmesi gerektiği.

Yapılan çalışmaların önemli bir bölümü öğretmenlerin sınıf içi ölçme ve değerlendirme bilgi ve becerilerinin istenen ve olması gereken düzeyin altında olduğunu göstermiştir (Bıçak ve Çakan, 2004; Daniel ve King, 1998; Güven, 2001). Ögrretmenlerin sınıf içi ölçme ve değerlendirme bilgi ve becerilerini saptamaya yönelik yurt içi ve yurt dışında çeşitli çalışmalar yapılmıştır. Yurt dışında yapılan çalışmalardan biri Cizek, Fitzgerald ve Rachor (1996) tarafından gerçekleştirilmiştir. Araştırmacılar 143 ilk ve ortaokul öğretmeni ile gerçekleştirdikleri çalışmada bu öğretmenlerin yaptıkları ölçme ve değerlendirme etkinliklerinin oldukça yüksek güvenirliğe sahip olduğunu saptamışlardır. Ayrıca cinsiyet, kıdem ve okuttukları sınıf düzeyi gibi değişkenlerin öğretmenlerin yaptıkları bu etkinliklerin güvenirliğini etkilemediği saptanmıştır. 
Cizek, Fitzgerald ve Rachor (1996) in bulgularının aksine, Daniel ve King (1998) 95 ilk ve ortaöğrenimde görevli öğretmen ile yaptıkları araştırmada bu öğretmenlerin ölçme ve değerlendirme konularında yeterince kapsamlı bir bilgiye sahip olmadıklarını saptamışlardır. Bu öğretmenlerin, ölçme ve değerlendirme çalışmalarında kullanılan basit istatistiki bilgilere sahip olmadıkları saptanmıştır. İlk ve ortaöğrenimde görevli öğretmenler bu konularda sahip oldukları bilgi ve beceri açısından karşılaştırıldıklarında aralarında anlamlı bir fark olmadığı gözlenmiştir. Çalışmada ayrıca Cizek, Fitzgerald ve Rachor'ın (1996) bulgularını destekler sonuçlar da elde edilmiştir. Buna göre öğretmenler kıdemleri ve okuttukları sınıf düzeyi açısından incelendiklerinde de aralarında anlamlı bir bilgi farkı olmadığı saptanmıştır. Yeni yada tecrübeli öğretmenlerin ve aynı şekilde hangi sınıf düzeyinde görevli olurlarsa olsunlar öğretmenlerin aynı ölçme ve değerlendirme bilgi ve becerisine sahip oldukları gözlenmiştir.

Diğer bir çalışmada Zhang ve Burry-Stock (2003) 297 ilköğretim ve ortaöğretim de görevli öğretmenin ölçme ve değerlendirme uygulamalarında kendilerini ne düzeyde yeterli algıladıklarını ve ne tür ölçme ve değerlendirme uygulamaları yaptıklarını incelemişlerdir. Araştırmada öğretmenlerin öğretim yaptığı kademe yükseldikçe objektif test kullanımına, kağıt - kalem testlerine (yazılı yoklama, çoktan seçmeli, kısa cevap vb.) daha fazla yöneldikleri bulunmuştur. Araştırmada ortaöğretimdeki öğretmenlerin kağıt-kalem testlerini daha fazla kullandıkları ve yaptıkları ölçme işlemlerinin kalitesi hakkında daha fazla kaygı taşıdıkları ve titizlik gösterdikleri halde ilköğretim öğretmenlerinin objektif test türlerine alternatif olarak performansa dayalı ölçme tekniklerini daha çok kullandıkları saptanmıştır. Öğretmenlerin kıdemleri ne olursa olsun ölçme ve değerlendirme alanında aldıkları eğitim düzeyi yada miktarı arttıkça bu alanda kendilerini daha yeterli hissettiklerini belirtmişlerdir. Araştırmada ayrıca üniversitelerde okutulan ölçme ve değerlendirme derslerinin ve bunların gerçek hayattaki ihtiyaçlara uygun planlanmasının önemi vurgulanmıştır.

Yurtiçinde yapılan çalışmalardan biri Yanpar (1992) tarafından ilkokul öğretmenleri ile gerçekleştirilmiştir. Öğretmenler çeşitli alanlarda bilgi eksikliği içinde olduklarını belirtmişlerdir. Bu bilgi eksikliklerinin başında öğrenci başarısı ölçüldükten sonra bu sonuçları nasıl değerlendirecekleri ve nasıl bir yargıya varacakları konularındadır. Çalışmada ayrıca öğretmenler yaşadıkları ölçme ve değerlendirme ile ilgili sorunlara yönelik hizmet içi eğitim ihtiyaçlarını dile getirmişlerdir.

İlköğretim öğretmenlerine yönelik diğer bir çalışma ise Güven (2001) tarafından gerçekleştirilmiştir. Çalışmaya katılan 120 sınıf öğretmeninin \%77 gibi önemli bir çoğunluğu ölçme ve değerlendirme uygulamalarında ve bu alandaki bilgi ve beceriler açısından kendilerini yeterli gördüklerini ifade 
etmişlerdir. Ayrıca, öğretmenler en sık kullandıkları madde türünün çoktan seçmeli maddeler olduğunu belirtmiş̧lerdir. Öğretmenler daha çok mutlak değerlendirme yaptıklarını, soru hazırlarken konuların önem sırasını dikkate aldıklarını, kavrama düzeyini de ölçen sorular sorduklarını, yazılı yoklamaları okurken puanlama hatasını engellemek için cevap anahtarı kullandıklarını, öğrencileri ve bazen de velileri de sınav sonuçlarından haberdar ettiklerini, öğrencilerin hatalarını görmeleri için sınav kağıtlarını görmelerine izin verdiklerini belirtmişlerdir. Çalışmada öğretmenlerin \%76 lik bir bölümünün ölçme ve değerlendirme konusunda eksikliklerini gidermek, bilgilerini geliştirmek ve yeni gelişmelerden haberdar olmak amacıyla hizmet içi eğitime ihtiyaç duydukları saptanmıştır. Bu sonuç diğer bazı çalışmaları destekler niteliktedir (Temel, 1991; Yanpar, 1992).

Diğer bir çalışma Temel (1991) tarafından ortaöğretim kademesinde görev yapan öğretmenler ile gerçekleştirilmiştir. Öğretmenler objektif ölçme yaptıklarına inandıklarını ifade etmişlerdir. Ancak öğretmenler, Yanpar (1992) ve Güven (2001) in çalışmasında saptandığ gibi, ölçme ve değerlendirme konusunda bilgi eksiklerinin olduğunu ifade etmişlerdir.

Benzer şekilde Mertler (1999) toplam 625 ilk ve ortaöğretimde görevli öğretmenin kullandıkları test tekniklerini ve bunları kullanma sıklıklarını araştırmıştır. Araştırmada lise öğretmenlerinin çoktan seçmeli testleri ilk ve ortaokul öğretmenlerinden daha sık kullandıkları saptanmıştır. Benzer şekilde ilkokul ve lise öğretmenlerinin de orta okul öğretmenlerinden daha sık çoktan seçmeli testleri kullandıkları saptanmıştır. İlkokul öğretmenleri çoğunlukla gözlem tekniğini kullandıklarını belirtmişlerdir. Araştırma bulguları Zhang ve Burry-Stock' in (2003) bulgularıyla bazı benzerlikler göstermektedir. Çalışmada ayrıca ilk, orta ve lise öğretmenlerinin boşluk doldurma, kısa cevap ve yazılı yoklama kullanma sıklığı bakımından benzer oldukları gözlenmiştir. Bu üç grup öğretmen yaptıkları ölçmelerin yarısını boşluk doldurma, kısa cevap ve yazılı yoklama tipi maddeleri kullanarak yaptıklarını belirtmişlerdir. Çalışmada ayrıca eğitim fakültelerinde okutulan ölçme ve değerlendirme derslerinin öğretmenlerin pratikte ihtiyaçlarını karşılayacak nitelikte geliştirilmesi ve gözden geçirilmesi gerektiği vurgulanmıştır.

Öğretmenlerin eksik yada yetersiz bilgi ve beceriye sahip oldukları ölçme ve değerlendirme tekniklerini uygulamaları sakıncalı sonuçlar doğurmaktadır. Fakat araştırmalar göstermektedir ki yetersiz oldukları durumlarda bile öğretmenlerin bir kısmı çeşitli ölçme ve değerlendirme tekniklerini uygulamaktadırlar ( Hills, 1991; Nolen, Haladyna, ve Haas, 1992; Stiggins ve Conklin, 1992; Plake, 1993). Bu durum çeşitli sakıncalar doğurmaktadır. Faydalı bir teknik yanlış şartlarda kullanıldığı yada doğru zamanda yanlış kullanıldığ için fayda yerine zarara neden olabilmektedir. $\mathrm{Bu}$ zarar en başta öğrenci olmak üzere, öğretim programına, öğretim 
ortamına yönelik yanlış yada eksik kararların alınması şeklinde gerçekleşebilmektedir.

$\mathrm{Bu}$ alandaki eksiklerin ve ihtiyaçların saptanması, gerekli önlemlerin alınması ve dolayısıyla eğitimin kalitesinin artırılması, öğretmenlerin kendilerini geliştirmelerine olanak sağlanması için öğretmenlerin ölçme ve değerlendirme uygulamaları düzenli olarak izlenmeli, saptanan eksiklikleri gidermeye yönelik tedbirler alınmalıdır. Çalışmanın bu ihtiyaca katkı getireceği umulmaktadır.

\section{Araştırmanın Amacı}

$\mathrm{Bu}$ araştırmanın amacı ilk ve ortaöğretim kademesinde görev yapmakta olan öğretmenlerin sınıf içi ölçme ve değerlendirme uygulamalarının neler olduğunu, ölçme ve değerlendirme alanında kendilerini ne düzeyde yeterli algıladıklarını ve bu konularda ilk ve ortaöğretim de görevli öğretmenler arasında ne gibi farklılıklar olduğunu araştırmaktır. $\mathrm{Bu}$ amaçları gerçekleştirmek için aşağıdaki sorulara cevaplar aranmıştır.

\section{Araştırma soruları}

1. İlk ve ortaöğretimde görevli öğretmenler ölçme ve değerlendirme alanındaki yeterlikleri açısından kendilerini nasıl algılamaktadırlar?

2. İlk ve ortaöğretimde görevli öğretmenlerin ölçme ve değerlendirme alanındaki yeterlikleri açısından kendilerini algılama düzeyleri arasında anlamlı bir fark var mıdır?

3. İlk ve ortaöğretimde görevli öğretmenlerin ölçme ve değerlendirme uygulamaları nelerdir

4. İlk ve ortaöğretimde görevli öğretmenlerin ölçme ve değerlendirme uygulamaları arasında anlamlı bir farklılık var mıdır?

\section{YÖNTEM}

\section{Katılımcilar}

Çalışma grubu, 2003-2004 eğitim- öğretim yılı yaz döneminde, Bolu ilinde düzenlenen "Eğitimde ölçme ve değerlendirme semineri" ne katılan öğretmenlerden oluşmaktadır. Katılım gönüllülük esasına göre yapılmıştır. Katılımcılar, sonuçların araştırma amaçları dışında başka bir amaçla kullanılmayacakları konusunda temin edilmişlerdir. Çalışma grubu, ilköğretimde görevli $260(\% 51,6)$ ve ortaöğretimde görevli $244(\% 48,4)$ olmak üzere toplam 504 öğretmenden oluşmaktadır. Katılımcıların $275 \mathrm{i}$ $(\% 54,6)$ kadın, 227 si $(\% 45)$ erkek öğretmenlerden oluşmaktadır. $2(\% 0.4)$ katılımcı cinsiyet bilgisini eksik bırakmıştır. 


\section{Veri Toplama Aracı}

Araştırmada öğretmenlerin ölçme ve değerlendirme etkinliklerini ve bu alandaki yeterlik düzeylerini saptamaya yönelik 25 soruluk bir anket geliştirilmiştir. Maddeler Likert tipi beşli dereceleme ölçeği formatında hazırlanmıştır. Anketteki maddelerin saptanması amacıyla literatür taraması yapılmış ve çıkan sonuçlar dahilinde öğretmenlerin ölçmenin hangi boyutlarına dönük olarak görüş bildirebilecekleri tespit edilmeye çalışılmıştır. Hazırlanan ankete ilişkin uzman görüşleri alınarak anketin kapsam ve ifade yeterliklerini sağlamaya yönelik gerekli düzeltmeler yapılmıştır. Ancak uygulama sırasında anketteki 7. maddenin katılımcılar tarafından anlaşılmadığ madde sayısı 24'e indirilmiştir.

Anketi oluşturan maddeler öğretmenlerin hangi tür ölçme araçlarını kullandıklarını, bunların kullanım sıklıklarını, kullanılan ölçme araçlarına yönelik ne tür güvenirlik ve geçerlik artırıcı önlemleri aldıklarını, kullandıkları maddelerin ne tür üst düzey zihinsel becerileri ölçtüklerini, objektif değerlendirme için alınabilecek tedbirlerle ilgili neler yaptıklarını tespit etmeye yönelik maddelerdir. Toplam 24 maddeden oluşan anket maddeleri (Bkz. Ek 1) ölçtükleri özellik bakımından dört alt boyuta ayrılmıştır. Anket incelendiğinde 6 madde öğretmenlerin sınıf içi ölçmelerde kullandıkları madde tipini saptamaya yönelik $(8,9,10,11,12,13), 3$ madde öğretmenlerin üst düzey zihinsel becerileri ölçüp ölçmediklerini saptamaya yönelik $(14,15,16), 13$ madde ise öğretmenlerin kullandıkları ölçme ve değerlendirme etkinliklerinin geçerlik ve güvenirliklerine dair neler yaptıklarını saptamaya yönelik $(2,3,4,5,6,17,18,20,21,22,23,24,25)$, ve 2 madde ise $(1,19)$ program sürecine dair bazı etkinlikleri saptamaya yönelik maddelerden oluşmaktadır.

Katılımcilar her bir madde de belirtilen ifade yada etkinliği ne s1klıkta gerçekleştirdiğini hiçbir zaman, çok seyrek, ara sıra, çoğu zaman, her zaman seçeneklerinden birini işaretleyerek belirtmişlerdir. Puanlama yapılırken olumlu ifadelerde her zaman 5, çoğu zaman 4, ara sıra 3, çok seyrek 2 ve hiçbir zaman 1 olarak puanlanmıştır. Olumsuz ifadelerden oluşan maddeler $(3,21,22,23,24,25)$ ters çevrilerek puanlanmıştır.

\section{BULGULAR}

Araştırma bulguları aşağıdaki alt başlıklar halinde sunulmuştur.

\section{1.Çalışma grubunun bazı değişkenler açısından betimlenmesi}

Katılımcıların cinsiyetleri, hizmet yılı ve branşlara dağılımı bulundukları öğretim kademesi de dikkate alınarak Tablo 1 de verilmektedir. 
Tablodan da anlaşıldığı üzere katılımcıların cinsiyetlere, öğretim kademelerine ve branşlara dağılımları dengeli gözükmektedir.

\section{2.Öğretmenlerin ölçme ve değerlendirmeye ilişkin kendi yeterliklerini algılama düzeyleri}

Tablo 2' de öğretmenlerin bulundukları öğretim kademesi de dikkate alınarak ölçme ve değerlendirme alanında kendilerini ne derecede yeterli algıladıklarına ilişkin frekans ve yüzdeler verilmiştir. Tablo 2'de de görüldüğü üzere hangi kademede çalışyor olurlarsa olsunlar

Tablo 1. Katılımcılara ilişkin demografik özellikler

\begin{tabular}{|c|c|c|c|c|c|c|c|c|c|c|c|}
\hline & & \multicolumn{6}{|c|}{ İlköğretim Kademesi } & \multicolumn{2}{|c|}{ Ortaöğr. } & \multicolumn{2}{|c|}{ Toplam } \\
\hline \multirow{6}{*}{$\frac{\sqrt{2}}{2}$} & \multirow[t]{3}{*}{ Değişken } & \multirow{2}{*}{\multicolumn{2}{|c|}{$\begin{array}{l}\text { İlköğr. } \\
\text { 1.kademe }\end{array}$}} & \multirow{2}{*}{\multicolumn{2}{|c|}{$\begin{array}{l}\text { İlköğr. } \\
\text { 2.kademe }\end{array}$}} & \multirow{2}{*}{\multicolumn{2}{|c|}{$\begin{array}{l}\text { İlköğretim } \\
\text { Toplam }\end{array}$}} & \multicolumn{2}{|c|}{ Ortaöğr. } & & \\
\hline & & & & & & & & & & & \\
\hline & & $\mathrm{n}$ & $\%$ & $\mathrm{n}$ & $\%$ & $\mathrm{n}$ & $\%$ & $\mathrm{n}$ & $\%$ & $\mathrm{n}$ & $\%$ \\
\hline & Kadın & 60 & 50,4 & 38 & 65,5 & 147 & 56,5 & 128 & 52,7 & 275 & 54,8 \\
\hline & Erkek & 59 & 49,6 & 20 & 34,5 & 112 & 43,1 & 115 & 47,3 & 227 & 45,2 \\
\hline & Toplam & \multicolumn{2}{|c|}{119} & \multicolumn{2}{|c|}{58} & \multicolumn{2}{|l|}{259} & \multicolumn{2}{|c|}{243} & \multicolumn{2}{|l|}{502} \\
\hline \multirow{5}{*}{ 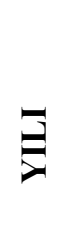 } & $0-5$ & 3 & 2,5 & 23 & 40,4 & 54 & 20,8 & 43 & 18,0 & 97 & 19,5 \\
\hline & $6-10$ & 12 & 10,1 & 15 & 26,3 & 48 & 18,5 & 69 & 28,9 & 117 & 23,5 \\
\hline & $11-15$ & 10 & 8,4 & 8 & 14 & 30 & 11,5 & 43 & 18,0 & 73 & 14,7 \\
\hline & $16-20$ & 16 & 13,4 & 4 & 7 & 28 & 11,5 & 38 & 15,9 & 66 & 13,3 \\
\hline & $21-25$ & 34 & 28,6 & 3 & 5,3 & 47 & 18,1 & 25 & 10,5 & 72 & 14,5 \\
\hline \multirow{3}{*}{$\underset{\mathbf{N}}{\mathbf{N}}$} & $26-30$ & 34 & 28,6 & 4 & 7 & 42 & 16,2 & 20 & 8,4 & 62 & 12,4 \\
\hline & 30-üstü & 10 & 8,4 & 0 & 0 & 10 & 3,8 & 1 & , 4 & 11 & 2,2 \\
\hline & Toplam & \multicolumn{2}{|l|}{119} & \multicolumn{2}{|c|}{57} & \multicolumn{2}{|l|}{259} & \multicolumn{2}{|c|}{239} & \multicolumn{2}{|l|}{498} \\
\hline \multirow{9}{*}{$\frac{\pi}{\infty}$} & Fen Bil. & - & & - & & - & & 36 & 15,3 & 36 & 7,7 \\
\hline & Sosyal Bil. & - & & 11 & 23,4 & 16 & 6,8 & 44 & 18,6 & 60 & 12,8 \\
\hline & Dil Bil. & - & & 6 & 12,8 & 44 & 18,8 & 35 & 14,8 & 79 & 16,8 \\
\hline & Matematik & - & & 9 & 19,1 & 16 & 6,8 & 26 & 11 & 42 & 8,9 \\
\hline & Beden/san. & - & & 10 & 21,3 & 21 & 9 & 15 & 6,4 & 36 & 7,7 \\
\hline & Teknikbil. & - & & 11 & 23,4 & 19 & 8,1 & 79 & 33,5 & 98 & 20,9 \\
\hline & Sınıf Öğrt. & 119 & 100 & - & & 118 & 50,4 & - & & 119 & 25,3 \\
\hline & \multirow[t]{2}{*}{ Toplam } & 119 & & 47 & & 234 & & 236 & & 470 & \\
\hline & & 175 & 34,7 & 58 & 11,5 & 260 & 51,6 & 244 & 48,4 & 504 & \\
\hline
\end{tabular}


öğretmenlerin önemli bir çoğunluğu (\% 62.9 - 82.8) kendilerini yetersiz olarak görmektedirler. Yine öğretmenlerin toplam \%16.1' i kendisini ölçme ve değerlendirme alanında eksik görmektedirler. Öğretmenlerin çok küçük bir bölümü kendilerini bu alanda yeterli olarak değerlendirmişlerdir (\% 1.6 9.1). Öğretmenlerin bir bölümü bu soruyu yanıtsız bırakmışlardır (\% 24).

Öğretim kademesi ve yeterlik düzeyleri arasında anlamlı ilişki olup olmadığı ayrıca ki kare testi ile yoklanmıştır. Öncelikle öğretim kademesi ilköğretim ve ortaöğretim olmak üzere iki grup olarak alınmış ve öğretim kademesi ile yeterlik düzeyleri arasında ki ilişki incelenmiştir. İki değişken arasında anlamlı bir ilişki bulunmuştur (Ki-kare $=11,145, \mathrm{sd}=2, \mathrm{P}=.004)$. Öğretmenlerin algıları bulundukları öğretim kademesine göre değişmektedir. İlköğretim kademesindeki öğretmenler ortaöğretim kademesindeki öğretmenlere kıyasla kendilerini daha yeterli görmektedirler.

Tablo 2. Öğretmenlerin ölçme ve değerlendirme alanındaki yeterlik düzeyleri

\begin{tabular}{|c|c|c|c|c|c|c|c|c|c|c|}
\hline \multirow{3}{*}{$\begin{array}{l}\text { Ölcme } \\
\text { Düzeyi }\end{array}$} & \multicolumn{6}{|c|}{ İlköğretim Kademesi } & \multicolumn{2}{|c|}{ Ortaöğretim } & \multirow{2}{*}{\multicolumn{2}{|c|}{$\begin{array}{l}\text { Genel } \\
\text { Toplam }\end{array}$}} \\
\hline & \multicolumn{2}{|c|}{$\begin{array}{l}\text { İlköğr. } \\
\text { 1.kademe }\end{array}$} & \multicolumn{2}{|c|}{$\begin{array}{l}\text { İlköğr. } \\
\text { 2.kademe }\end{array}$} & \multicolumn{2}{|c|}{$\begin{array}{l}\text { İlköğr. } \\
\text { Toplam }\end{array}$} & \multirow[b]{2}{*}{$\mathrm{n}$} & \multirow[b]{2}{*}{$\%$} & & \\
\hline & $\mathrm{n}$ & $\%$ & $\mathrm{n}$ & $\%$ & $\mathrm{n}$ & $\%$ & & & $\mathrm{n}$ & $\%$ \\
\hline Yetersiz & 56 & 62,9 & & 0,5 & 131 & 68,6 & 159 & 82,8 & 290 & 57,5 \\
\hline Eksik & 31 & 34,8 & & 0,5 & 51 & 26,7 & 30 & 15,6 & 81 & 16,1 \\
\hline Yeterli & 2 & 2,2 & & 9,1 & 9 & 4,7 & 3 & 1,6 & 12 & 2,4 \\
\hline Toplam & 89 & & 44 & & 191 & & 192 & & 383 & 76 \\
\hline
\end{tabular}

Aynı şekilde ilköğretim kademesi kendi içinde 1. ve 2. kademe olarak ayrılıp ortaöğretimde dahil olmak üzere 3 grup şeklinde alındığında yine öğretim kademesi ile kendini algılama arasında anlamlı bir ilşki bulunmuştur ( $\mathrm{Ki}$-kare $=17,851, \mathrm{sd}=4, \mathrm{P}=.001$ ). Buna göre öğretmenlerin kendilerini nasıl algıladıkları onların çalıştıkları kademeye göre farklılık göstermektedir.

Genel olarak bakıldığında görülmektedir ki bütün öğretim kademelerinde öğretmenlerin oldukça büyük bir kısmı kendini yetersiz olarak algılamaktadır.

3. İlk ve ortaöğretimde görevli öğretmenlerin ölçme ve değerlendirme uygulamaları arasındaki farkın incelenmesi

Tablo 3' de ilk ve ortaöğretimde görevli öğretmenlerin anketteki üç alt boyutta aldıkları puanlara ait ortalamalar verilmektedir. Görüldüğü gibi ortalamalar birbirine oldukça yakın bulunmaktadır. Farklı kademelerdeki öğretmenlerin soru düzeyi, geçerlik-güvenirlik ve program süreci 
boyutlarında aldıkları puan farkları üç-yönlü varyans analizi ile test edilmiştir (Tablo 3).

Sonuçlara göre alt boyutların hiçbirinde ilköğretim ve ortaöğretim de görevli öğretmenler farklılık göstermemişlerdir. Ortalamaların yakınlığı da bunu desteklemektedir. Kullandıkları soru düzeyleri açısından incelendiklerinde, öğretmenlerin kullandıkları soruların düzeyleri öğretmenlerin görev yaptıkları kademeye göre farklılaşmamaktadır. Aynı şekilde, öğretmenlerin kullandıkları ölçme ve değerlendirme etkinliklerinin güvenirlik ve geçerliklerine yönelik aldıkları tedbirler ve program sürecine yönelik tedbirler öğretmenlerin bulundukları öğretim kademesine göre farkl11ık göstermemektedir.

Tablo 3. Öğretmenlerin her bir boyuttaki puan farklarına ilişkin varyans analizi sonuçları

\begin{tabular}{lccrc}
\hline & İlkö̆ğretim & Ortaöğretim & F & P \\
\cline { 2 - 5 } \multicolumn{1}{c}{ Boyutlar } & $\overline{\mathrm{X}}$ & $\overline{\mathrm{X}}$ & & \\
\hline Soru düzeyi & 10,40 & 10,16 &, 981 &, 323 \\
Geç-güvenirlik & 53,28 & 53,92 & 1,480 &, 224 \\
Program süreci & 7,45 & 7,27 & 1,911 &, 167 \\
\hline
\end{tabular}

İlk ve ortaöğretimde görev yapan öğretmenlerin kullandıkları soru tipi açısından farklı yaklaşımlara sahip olup olmadıkları da ayrıca incelenmiştir (Tablo 4).

Tablo 4. Kullanılan madde türleri ve bunların ilk ve ortaöğretimde görevli öğretmenler tarafından kullanım sıklıkları

\begin{tabular}{|c|c|c|c|c|c|c|c|c|c|c|c|c|}
\hline \multirow[t]{4}{*}{ İLKÖĞRETİM } & \multirow{3}{*}{\multicolumn{2}{|c|}{$\begin{array}{l}\text { Çoktan } \\
\text { Seçmeli }\end{array}$}} & \multirow{3}{*}{\multicolumn{2}{|c|}{$\begin{array}{l}\text { Yazılı } \\
\text { Yoklama }\end{array}$}} & \multirow{3}{*}{\multicolumn{2}{|c|}{$\begin{array}{l}\text { Kısa } \\
\text { Cevap }\end{array}$}} & \multirow{3}{*}{\multicolumn{2}{|c|}{$\begin{array}{l}\text { Boşluk } \\
\text { Doldurma }\end{array}$}} & \multirow{2}{*}{\multicolumn{2}{|c|}{ Dogru/ Yanlış }} & \multirow{2}{*}{\multicolumn{2}{|c|}{ Eşleştir. }} \\
\hline & & & & & & & & & & & & \\
\hline & & & & & & & & & \multirow[t]{2}{*}{$\mathbf{n}$} & \multirow[t]{2}{*}{$\%$} & \multirow[b]{2}{*}{$\mathbf{n}$} & \multirow[b]{2}{*}{$\%$} \\
\hline & n & $\%$ & n & $\%$ & n & $\%$ & n & $\%$ & & & & \\
\hline Hiçbirzaman & 17 & 6,5 & 17 & 6,5 & 22 & 8,5 & 32 & 12,3 & 52 & 20,0 & 47 & 18,1 \\
\hline Çok seyrek & 33 & 12,7 & 48 & 18,5 & 34 & 13,1 & 46 & 17,7 & 55 & 21,2 & 59 & 22,7 \\
\hline Ara Sira & 49 & 18,8 & 57 & 21,9 & 71 & 27,3 & 86 & 33,1 & 72 & 27,7 & 73 & 28,1 \\
\hline Çoğu Zaman & 86 & 33,1 & 90 & 34,6 & 75 & 28,8 & 57 & 21,9 & 49 & 18,8 & 50 & 19,2 \\
\hline Her Zaman & 60 & 23,1 & 37 & 14,2 & 45 & 17,3 & 27 & 10,4 & 22 & 8,5 & 16 & 6,2 \\
\hline \multicolumn{13}{|c|}{ ORTAÖĞRETIMM } \\
\hline Hiçbirzaman & 19 & 8,3 & 7 & 3,0 & 21 & 9,3 & 72 & 31,6 & 100 & 43,9 & 85 & 38,1 \\
\hline Çok seyrek & 66 & 28,8 & 25 & 10,8 & 52 & 22,9 & 44 & 19,3 & 58 & 25,4 & 57 & 25,6 \\
\hline Ara Sira & 75 & 32,8 & 38 & 16,5 & 84 & 37,0 & 65 & 28,5 & 48 & 21,1 & 55 & 24,7 \\
\hline Çoğu Zaman & 43 & 18,8 & 99 & 42,9 & 50 & 22,0 & 29 & 12,7 & 14 & 6,1 & 20 & 9,0 \\
\hline Her Zaman & 26 & 11,4 & 62 & 26,8 & 20 & 8,8 & 18 & 7,9 & 8 & 3,5 & 6 & 2,7 \\
\hline
\end{tabular}


Tablodan da anlaşıldığ1 üzere ilköğretim de görevli öğretmenler "her zaman" seçeneğini en çok çoktan seçmeli maddeler için kullanmışlardır (\% 23.1). Bunu kısa cevap, yazılı yoklama, boşluk doldurma, doğru-yanlış ve eşleştirme maddeleri izlemektedir. Orta öğretimde ise bu seçenek en fazla yazılı yoklamalar için kullanılmıştır $(\% 26,8)$. Bunu sırasıyla çoktan seçmeli, kısa cevap, boşluk doldurma, doğru-yanlış ve eşleştirme maddeleri izlemektedir.

"Çoğu zaman" seçeneği ilköğretim de görevli öğretmenler tarafından en çok yazılı yoklamalar için kullanılmış $(\% 34,6)$ ve bunu sırasıyla çoktan seçmeli,kısa cevap, boşluk doldurma, eşleştirme ve doğru-yanlış maddeleri izlemektedir. Orta öğretimde ise bu seçenek en fazla ve büyük oranla yazılı yoklamalar için kullanılmıştır (\%42.9). Bunu yine sırasıyla kısa cevap, çoktan seçmeli, boşluk doldurma, eşleştirme ve doğru-yanlış maddeleri izlemektedir.

Ara sıra seçeneği yine ilköğretimde en sik boşluk doldurma maddeleri için kullanılmıştır (\%33.1). Bunu eşleştirme, doğru-yanlış, kısa cevap, yazılı yoklama ve çoktan seçmeli maddeler izlemektedir. Orta öğretimde ise bu seçenek en fazla kısa cevap maddeleri (\%37) için kullanılmış. Bunu çoktan seçmeli, boşluk doldurma, eşleştirme, doğru-yanlış ve yazılı yoklama izlemektedir.

Çok seyrek seçeneği yine ilköğretimde en fazla eşleştirme, sonra doğruyanlış, yazılı yoklama, boşluk doldurma, kısa cevap ve çoktan seçmeli maddeler için kullanılmıştır. Orta öğretimde ise bu seçenek en fazla çoktan seçmeli (\%28.8) eşleştirme, doğru yanlış, kısa cevap, boşluk doldurma, ve yazılı yoklama için kullanılmıştır.

Hiçbir zaman seçeneği yine ilköğretimde en sık doğru yanlış maddeler de kullanılmış ve bunu sırasıyla eşleştirme, boşluk doldurma, kısa cevap ve eşit oranlarla yazlı yoklama ve çoktan seçmeli maddeler izlemiştir. Ortaöğretimde ise en s1k doğru yanlış (43.9), ve sonra eşleştirme, boşluk doldurma, kısa cevap, çoktan seçmeli ve yazılı yoklamalar için kullanılmıştır.

\section{SONUÇ VE TARTIŞMA}

Bulgular öğretmenlerin oldukça büyük bir kısmının ölçme ve değerlendirme konusunda kendilerini yetersiz yada eksik bulduklarını göstermiştir. Bu sonuç literatürle de paralellik göstermektedir (Bıçak ve Çakan, 2004; Daniel ve King, 1998; Güven, 2001; Temel, 1991; Yanpar,1992). Öğretmenlerin eksik yada yetersiz oldukları konularda hizmet içi eğitimle eksikliklerinin giderilmesi gerekmektedir (Güven, 2001; Mertler, 1999; Temel, 1991; Yanpar, 1992). Ayrıca eğitim fakültelerinin 
öğretim programlarında ölçme ve değerlendirmeye yönelik derslere daha fazla yer verilmesi ve bu derslerinde öğretmenlerin meslek sırasında ihtiyaç duydukları bilgi ve becerilere cevap verir nitelikte olması gerekmektedir (Gullickson, 1984; Lissitz, 1987; Mertler, 1999; Zhang, Burry-Stock, 2003). Ayrıca çalışma da ilköğretim kademesinde ki öğretmenlerin ortaöğretim kademesinde görevli öğretmenlerle kıyaslandığında kendilerini daha yeterli algılama eğiliminde oldukları görülmektedir. Ortaöğretim kademesinde daha fazla öğretmen kendini yetersiz olarak nitelemiştir.

Bununla beraber, ölçme ve değerlendirme etkinliklerinin güvenirlik ve geçerliğini artırıcı tedbirler alma açısından, program sürecine yönelik tedbirler ve kullandıkları soru düzeyleri açısından öğretmenler arasında anlamlı bir fark bulunamamıştır. Öğretmenler bu konularda benzer davranmaktadırlar.

Kullandıkları madde türü açısından bakıldığında, ilköğretim kademesindeki öğretmenlerin \% 56.2 oranla en çok çoktan seçmeli maddeleri kullandıkları ("her zaman" ve "çoğu zaman" seçeneklerinin toplami) ve bunu $\% 48.8$ ve $\% 46.1$ ile yazılı yoklama ve k1sa cevapl maddelerin izlediği fakat ortaöğretim öğretmenlerinin en çok yazılı yoklamaları kullandıkları $(\% 69.7)$ ve bunu $\% 30.8$ ve $\% 30.2$ oranla kısa cevap maddeleri, çoktan seçmeli maddelerin izlediği görülmektedir. Bu oranlar "her zaman" ve "çoğu zaman" seçeneklerinin toplanmasiyla elde edilmiştir. İlköğretim öğretmenlerinin ortaöğretim öğretmenlerinden daha fazla çoktan seçmeli madde kullanması ilginçtir. Çünkü ilköğretimde öğrencilerin sözel becerilerinin, kendini yazılı olarak ifade etme becerilerinin ve yaratıcılık güçlerinin gelişmesi açısından yazılı yoklamaların çoktan seçmelilerden daha sık kullanılması beklenen bir durumdur. Fakat ortaöğretim öğretmenlerinin büyük bir çoğunluğu yazılı yoklamayı tercih ederken ilköğretim öğretmenleri çoktan seçmelileri kullanmayı tercih etmektedirler. Öğrencilerin ortaöğretime giriş sınavlarıla karşı karşıya kalması ve bu sınavların çoktan seçmeli formatta olması bu durumu teşvik eden nedenlerden biri olarak düşünülebilir. Bu konunun ayrıca araştırılması gerekmektedir.

Genel olarak, öğretmenlerin belli konularda bilgilendirilmeye ihtiyaç duydukları gözlemlenmektedir. Saptanan bu eksikleri Milli Eğitim ve üniversitelerin yapacağı bir işbirliğiyle giderilmesi eğitim sistemimizin sorunlarını belli oranda giderecektir. Bu tür çalışmalar devamlılık esasına göre sürdürülmelidir. 


\section{KAYNAKLAR}

Bıçak, B. ve Çakan, M. ( 20-22 Aralık 2004). Lise Öğretmenlerinin Sinıf İçi Ölçme ve Değerlendirme Uygulamalarına Dönük Görüşleri. Milli Eğitim Bakanlığı, Orta Öğretimde Yeniden Yapılanma Sempozyumunda sunulmuş bildiri, Ankara.

Cizek, G. J., Fitzgerald, S. M. \& Rachor, R. E. (1996). Teachers' assessment practices: Preparation, isolation, and the kitchen sink. Educational Assessment, 3(2), 159-179.

Daniel, L. G. \& King, D. (1998). A knowledge and use of testing and measurement literac of elementary and secondary teachers. Journal of Educational Research, 91 (6), 331-344.

Gullikson, A. R. (1984). Teacher perspectives of their instructional use of tests. Journal of Educational Research, 77(4), 244-248.

Gullikson, A. R. (1985). Student evaluation techniques and their relationship to grade and curriculum. Journal of Educational Research, 79 (2), 96-100.

Güven, S. (7-9 Haziran 2001). Sinlf ögrretmenlerinin ölçme ve değerlendirmede kullandıklarl yöntem ve tekniklerin belirlenmesi. 10. Ulusal Eğitim Bilimleri Kongresinde sunulmuş bildiri, Abant İzzet Baysal Üniversitesi, Bolu.

Hills, J.R. (1991). Apathy concerning grading and testing. Phi Delta Kappa, $72(7), 540-545$.

Kubiszyn, T. \& Borich, G. (1996). Educational testing and measurement: Classroom application and practice (5th ed.). New York: HarperCollins.

Mertler, C. A. (1999). Assessing student performance: A descriptive study of the classroom assessment practices of Ohio teachers. Education, 120 (2), 285-297.

Nolen, S. B., Haladyna, T. M. \& Haas, N. S. (1992). Uses and abuses of achievement test scores. Educational Measurement: Issues and Practice, 11 (2), 9-15.

Plake, B.S. (1993). Teacher assessment literacy: Teachers' competencies in the educational assessment of students. Mid-Western Educational Research, 6 (1), 21- 27.

Stiggins, R. J. \& Conklin, N. F. (1992). In teachers' hands: Investigating the practices of classrom assessment. Albany: State University of New York Press. 
Temel, A. (1991). “ Ortaöğretimde Ölçme ve Değerlendirme Sorunları”. Yaşadıkça Ĕ̈itim Dergisi, 18, 23-27.

Yanpar, T. (1992). "Ankara ilkokullarındaki ikinci devre ögretmenlerinin öğretmenlik mesleği ve konu alanlarıyla ilgili eğitim ihtiyaçları." Yayımlanmamış yüksek lisans tezi, Hacettepe Üniversitesi Eğitim Bilimleri Enstitüsü, Ankara.

Zhang, Z. \& Burry-Stock, J. A. ( 2003). Classroom assessment practices and teachers' self- perceived assessment skills. Applied Measurement in Education, 16 (4), 323-342. 


\section{EKLER}

EK -I

\begin{tabular}{|c|c|c|c|c|c|}
\hline 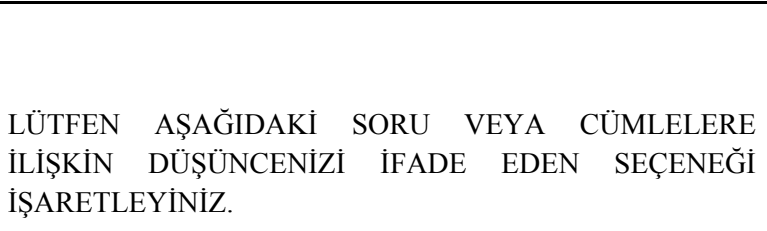 & 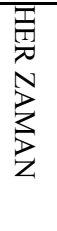 & 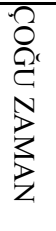 & $\begin{array}{l}\vec{D} \\
> \\
\Omega \\
\bar{D} \\
>\end{array}$ & 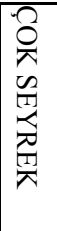 & 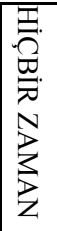 \\
\hline $\begin{array}{l}\text { 1.Tespit ettiğiniz öğrenme eksiklerini gidermek için zaman } \\
\text { ayırabiliyor musunuz? }\end{array}$ & & & & & \\
\hline 2.Hazırladığınız soruları her öğrenci aynı şekilde anlıyor mu? & & & & & \\
\hline $\begin{array}{l}\text { 3.Sorularınızı çözmek için konu alanı dışında beceriler } \\
\text { gerekiyor mu? }\end{array}$ & & & & & \\
\hline 4.Sorularınızı çözmek için yeterli zaman veriyor musunuz? & & & & & \\
\hline $\begin{array}{l}\text { 5.Puanlama yaparken cevabı bütün olarak okuyup sonra mı } \\
\text { puanlyyorsunuz. }\end{array}$ & & & & & \\
\hline $\begin{array}{l}\text { 6.Puanlama yaparken çözz̈me ilişkin süreci ayrı ayrı puanlayıp } \\
\text { sonra topluyormusunuz. }\end{array}$ & & & & & \\
\hline 8.Çoktan seçmeli testleri ne sıklıkta kullanıyorsunuz? & & & & & \\
\hline 9.Klasik yazılı yoklamaları ne sıklıkta kullanıyorsunuz? & & & & & \\
\hline 10.Kısa cevaplı testleri ne sıklıkta kullanıyorsunuz? & & & & & \\
\hline 11.Boşluk doldurma sorularını ne sıklıkta kullanıyorsunuz? & & & & & \\
\hline 12.Doğru-Yanlış soru tipini ne sıklıkta kullanıyorsunuz? & & & & & \\
\hline 13.Eşleştirme soru tipini ne sıklıkta kullanıyorsunuz? & & & & & \\
\hline 14.Öğrencinize analiz gücünü ölçen sorular soruyor musunuz? & & & & & \\
\hline 15.Öğrencinize sentez gücünü ölçen sorular soruyor musunuz? & & & & & \\
\hline $\begin{array}{l}\text { 16.Öğrencinize değerlendirme gücünü ölçen sorular soruyor } \\
\text { musunuz? }\end{array}$ & & & & & \\
\hline 17.Ayrıntılı cevap anahtarı hazırlyyor musunuz? & & & & & \\
\hline $\begin{array}{l}\text { 18.Öğrencilerinizin davranışlarını ölçerken ayrıntılı plan } \\
\text { yapıyormusunuz? }\end{array}$ & & & & & \\
\hline 19.İlgisiz öğrencileri tespit edici çalışmalar yapiyor musunuz? & & & & & \\
\hline 20.Yeterince objectif değerlendirmeler yapıyor musunuz? & & & & & \\
\hline $\begin{array}{l}\text { 21.Öğrencinizin haylaz ya da uslu oluşu puanlama yaparken } \\
\text { kararnnzı etkiliyor mu? }\end{array}$ & & & & & \\
\hline
\end{tabular}




\begin{tabular}{||l|l|l|l|l|l||}
\hline $\begin{array}{l}\text { 22.Öğrencinizin sınıfta başarılı olması puanlama yaparken } \\
\text { kararlarınızı etkiliyor mu? }\end{array}$ & & & & \\
\hline $\begin{array}{l}\text { 23.Öğrencinizin sosyo-ekonomik durumu puanlama yaparken } \\
\text { vereceğiniz kararı etkiliyor mu? }\end{array}$ & & & & \\
\hline 24.Öğrencinizin cinsiyeti puanlama yaparken etken oluyor mu? & & & & & \\
\hline $\begin{array}{l}\text { 25.Öğrenci hakkında verdiğiniz kararlardan dolayı pişmanlık } \\
\text { duyuyor musunuz? }\end{array}$ & & & & \\
\hline
\end{tabular}

\section{SUMMARY}

It is essential to monitor assessment applications that teachers carry out in classes. This is necessary to detect what kind of problems teachers experience during in class assessments and define teacher needs related to measurement and evaluation issues. Literature reveals that teachers encounter with many problems during their classroom assessments. Moreover, although they don't have enough skills and knowledge regarding various test techniques, nevertheless, they apply these techniques for classroom assessments (Hills, 1991; Nolen, Haladyna, ve Haas, 1992; Stiggins ve Conklin, 1992; Plake, 1993). This sutiation has its' consequenses which negativly effect decisions and feedbacks teachers made regarding their students, curriculums, and some other educational decisions, as well. Teachers shold be monitored and trained to improve their knowladge and skills in measurement field.

Present study aims to compare elementary and secondary school teachers in terms of their in class assessment activities and teacher perceptions toward their qualification levels related to their measurement and evaluation knowledge and skills. Twenty-five item survey developed by the researcher was administered to define teachers applications and perceptions related to various assessment issues. The participants were 260 elementary and 244 secondary school teachers who were attending inservice training program during summer of 2004. Of the participants, 275 $(\% 54,6)$ were females and $227(\% 45)$ were males. Participation to the study was volunteery. The findings revealed that most of the teachers from both groups perceived themselves as unqualified in various aspects of measurement and evaluation applications. It was also observed that they also spent effort to improve validity and reliability levels of tests and techniques they apply. Another finding of the study was that no significant difference between the two teacher groups were observed in terms of item levels they use to assess various cognitive skills, precautions they take to improve reliability and validity of assessments, and some other issues. 
Considering item types they use, most of the elementary school teachers reported that they use multiple choice items most often than any other type. On the other hand, secondary school teachers indicated that they prefer using essay tests most often than any other item type. It was interesting to find out that elementary school teachers rely on multiple choice items more than any other type test and more than even the secondary school teachers rely on, because elementary schools are important for children to improve their communication skills, verbal expirations etc. To assess these skills teachers need to apply essay exams or some other test forms that allow students to express these type skills. One reason for elementary school teachers to prefer multiple choice exams may be that there is a fact that after students complete elementary school, they need to take entrance exams to go to proper high schools. And these exams were given in multiple choice forms, therefore, children need to learn how to take this type exam. However, in order to come to conclusion and better understanding on this issue, further research is necessary.

Based on the findings of the study, it was suggested that teachers should be trained during in-service to improve themselves and cope with new developments in measurement field. It was also suggested that measurement courses taught in college of education should be reconsidered in terms of measurement and evaluation knowledge and skills they consist of and should be improved to provide teacher candidates with more adequate assessment skills and fulfill the needs of teachers. 